\title{
PRESENT SITUATION, CAPACITIES AND PROSPECTS OF DEVELOPMENT OF POULTRY PRODUCTION IN SERBIA
}

\author{
N. Milošević ${ }^{1}$ Z. Pavlovski ${ }^{2}$, L. Perić ${ }^{1}$ \\ ${ }^{1}$ Faculty of Agriculture, Trg Dositeja Obradovića 8, 21000 Novi Sad, Republic of Serbia \\ ${ }^{2}$ Institute for Animal Husbandry, Autoput 16, 11080 Belgrade-Zemun, Republic of Serbia \\ Corresponding author: nikom@polj.uns.ac.rs \\ Invited paper
}

Abstract: The paper gives review of the present situation, capacities and prospects of poultry production in Republic of Serbia. It was concluded that poultry production in the period 1990-2000 was mainly in stagnation. From maximum production of meat of 13,2 $\mathrm{kg}$ per capita in 1989, it dropped to under $6 \mathrm{~kg}$ in 1994, and production of eggs, from 230 eggs per capita in 1989 to 109 eggs in 1995. Also, reasons are stated for such poor condition, introduction of economic sanctions, transition processes and decline in the standard of living of the population. Beginning of the recovery of poultry production starts in 2000 , when conditions and situation in Serbia changed: the ownership transformation of companies was carried out, sanctions were lifted and inflow of foreign credits to our country began. Recovery is very slow and predictions are that this branch of economy will be fully recovered and revitalized in 2020, when it will be sufficiently efficient to be competitive on markets of EU developed countries. Expectations are realistic provided that objective and subjective difficulties are overcome, because natural resources for development of poultry breeding exist, to provide enough products for domestic population, but also for export and especially of products deriving from alternative production systems.

Key words: poultry production in Republic of Serbia, resources, present condition, improvement measures

\section{Introduction}

Production of poultry meat and eggs in Republic of Serbia in the previous period was mainly based on organizing of production on large, state owned, specialized farms, on family farms of lower capacity (several hundreds to thousands of layer hens and broilers in one cycle), and production in back yards (extensive) (Milošević and Perić, 2011). Potential of production of poultry meat and eggs in Republic of Serbia is enormous due to possibility of stable production of inexpensive livestock food (corn, soybean, sunflower, peas) and available production capacities for 
poultry rearing (Mihailovic et al., 2009). Production in the previous period was mainly very profitable business for those producers who respected and proceeded according to main principles of intensive poultry production.

Since poultry production is relatively inexpensive source of food of high quality, it is very important in Republic of Serbia, especially since we are the country which faced for the last two decades very difficult economical crisis and low standard of living, as consequence of long transition process which lasted two decades. Value of poultry production in Serbia is 215-220 million dollars, which is $12-14 \%$ of total livestock production (Munćan et al. 2005; Rodić et al. 2010; Economy, 2010). In contrast to its importance, in the last two decades this production decreased significantly. According to Rodić et al. (2010), several factors have contributed to this drop, including: significant decrease of domestic/national market, which started with disintegration of SFR Yugoslavia at the beginning of 1990-ties; decrease of demand for animal products due to decline of the standard of living; certification is not harmonized with EU standards, which is limiting factor for export to EU markets; inefficient process of privatization which caused bankruptcy of numerous state owned/public/ farms which once used to be carriers of the progress and pillar of poultry production; poultry products have become non-competitive on international markets because of high production costs; technical obsolescence of processing capacities and rather limited selection of finished poultry products; under developed vertical integration and poor connection between producers and participants in the whole chain of production; and lack of institutional support of the government to poultry production.

Difficulties which have burdened this production were objective, but there have been those of subjective nature. Problems occurred with the import of high quality breeding material, import of certain feeds, additives and most important of vaccines and medicines. As consequence, production and consumption of poultry meat dropped from record 13,2 $\mathrm{kg}$ of meat per capita in 1988 to under $6 \mathrm{~kg}$ in 1994, and consumption of eggs from 230 in 1989 to 109 in 1995 (Supić et al. 2000; SGS, 2010; FAOSTAT, 2010).

\section{Present situation in poultry production in Serbia}

Number of poultry in absolute amount did not decrease significantly, but there was the decline in the productivity of the production, especially on big state owned farms which underwent the change of ownership structure. Big farms based their production on high technology and use of productive hybrids of foreign origin, without any room for improvisation 
Table 1. Number of poultry in Republic of Serbia according to types of poultry (in 000)

\begin{tabular}{|l|c|c|c|c|c|}
\hline Year & Hens & Ducks & Geese & Turkeys & Total \\
\hline 1990 & 26.786 & 540 & 944 & 721 & 28.991 \\
\hline 1995 & 22.491 & 501 & 896 & 627 & 24.515 \\
\hline 2000 & 18.283 & 520 & 925 & 645 & 20.373 \\
\hline 2005 & 14.816 & 600 & 1.000 & 700 & 17.116 \\
\hline 2010 & 18.543 & 150 & 470 & 193 & 20.156 \\
\hline
\end{tabular}

Source: SGS (2010); Faostat (FAO.org)

Decrease of number of poultry in Serbia coincides with the disintegration of SFRY. Before, significant financial means were invested into building of primary production and processing facilities, which resulted in constant growth of poultry meat and egg production. Subsequently, to present day, poultry production hasn't recovered. Circumstances were such that the private sector consolidated and took over complete poultry production. Recently, several foreign companies appeared in Serbia, which invested significant financial means in Serbia's poultry production.

Serbia doesn't belong to countries with developed poultry production, since almost half of total number of poultry $(48,6 \%)$ is reared in village holdings, back yards, extensively, with significant share of primitive breeds and their crosses (Milošević and Perić, 2011). Of total number of poultry, the $90 \%$ are layer hens. There were some attempts to increase the share of other types of poultry, however, the market dictated such ratio. The consumption of turkey, geese and duck meat is by our domestic consumers is relatively low, and export very unsure and often without incentives, therefore this production is less profitable and associated with lot of risk. Products of these poultry species are mainly placed on the market in certain seasons - Christmas and New Year holidays, when due to high supply in short period it is not possible to realize adequate price compared to invested expenses and costs. This has been the reason for decrease in rearing of other poultry species by two and more times in previous years. Although until recently, Serbia was important exporter of geese meat and feathers and realized significant income from this export. On the territory of Republic of Serbia, today, there isn't any farm of high capacity engaged in rearing of turkeys, geese and ducks.

Even though Serbia owns significant potential for alternative poultry production, there aren't any farms which would supply poultry meat and eggs from alternative production systems, either from free range systems or organic production, although many studies have been done on the possibilities for production of meat and eggs in such production systems, as well as consumer surveys conducted on acceptability of these products (Pavlovski et al., 1999; Perić et al. 2003; Milošević et al. 2005; Lukić et al. 2008; Rodić et al. 2008). 
In Republic of Serbia, a law banning rearing of layer hens in cages, conditions for rearing in enriched cages and so called alternative housing systems which include floor system, aviary system, floor system with free range and organic production has been adopted. Housing is strictly regulated by legislation (Animal Welfare Law, "Official Journal of RS", No. 41/2009. and rulebooks and by-laws), which shall enter into force starting from year 2012. According to this law, producers are obligated to respect the conditions and requirements if they want to be engaged in poultry production and marketing of their products on domestic and EU markets (Peric et al. 2008; Pavlovski et al., 2010; Milošević and Perić, 2011; Škrbić et al.). Unfortunately, most of domestic producers feel that implementation of this law will be postponed since there aren't any realistic, objective conditions for its implementation and enforcing and they would simply have to stop with this production.

Table 2. Production of meat and eggs in Republic of Serbia

\begin{tabular}{|l|c|c|c|c|}
\hline \multirow{2}{*}{ Year } & \multicolumn{2}{|c|}{ Poultry meat } & \multicolumn{2}{c|}{ Eggs } \\
\cline { 2 - 5 } & Total, tons & Kg/per capita & Total, million pcs. & Eggs/ per capita \\
\hline 2000 & 89.100 & 8,4 & 1.374 & 131 \\
\hline 2007 & 91.163 & 8,7 & 1.364 & 130 \\
\hline 2008 & 76.203 & 10,2 & 1.204 & 160 \\
\hline 2009 & 80.120 & 10,9 & 1024 & 141 \\
\hline 2010 & 84.350 & 11,5 & 1219 & 167 \\
\hline
\end{tabular}

Source: SGJ (2010); Faostat (FAO.org)

Production of poultry meat, after suffering great decline in the first half of the 90-ties, is now continuously increasing with some oscillations, and the same trend is present in production of table eggs, with the exception of year 2009, which can be explained by recession and decline in purchasing power of the population, but also cyclic oscillations present on the market. Production and consumption of poultry meat per capita in Serbia show very slight difference since import of poultry meat in 2009 was only 367 tons and export 1.670 tons, and import and export of eggs are even lower (Bugarin, 2010).

\section{Production of poultry meat and eggs in Republic of Serbia and some countries of the world}

Often on meetings and conferences complaints by producers can be heard how the production of poultry meat and eggs is not profitable because of expenses and costs which cannot be covered by selling prices. Production cost of poultry (broiler) meat and eggs in the period 2005-2009 shows slight changes which are similar in all EU countries. In Brazil and USA, for several years, production cost 
has been lower by 10-20\% compared to EU countries (Van Horn, 2007; Milošević and Perić, 2008). In Serbia, production cost of poultry meat is higher by $30 \%$ compared to Brazil and USA, and by $10-20 \%$ compared to EU countries.

Table 3. Parameters of broiler production

\begin{tabular}{|l|c|c|c|c|c|c|c|c|}
\hline Parameters & NL & D & F & UK & PL & BR & SAD & SRB \\
\hline Cost of food (euro/100 kg) & 24,6 & 23,7 & 25,5 & 24,8 & 25,3 & 18,5 & 16,8 & 30,0 \\
\hline Cost of chicks (ct/chicken) & 27,5 & 27,4 & 26,5 & 31,2 & 24,3 & 19,0 & 14,6 & 35,2 \\
\hline Cost of broilers (euro/kg) & 0,84 & 0,84 & 0,87 & 0,81 & 0,92 & 0,72 & 0,69 & 1,03 \\
\hline Broiler live weight, g & 2.160 & 1.920 & 1.900 & 2.340 & 2.330 & 2.400 & 2.500 & 2.100 \\
\hline Feed conversion (farm) & 1,74 & 1,77 & 1,87 & 1,86 & 1,82 & 1,88 & 1,97 & 1,98 \\
\hline Broiler mortality, \% & 4,0 & 3,8 & 4,2 & 4,1 & 4,2 & 4,5 & 4,5 & 8,0 \\
\hline
\end{tabular}

Source: SGJ (2010); Faostat (FAO.org); Van Horne (2008).

Data presented in Table 3 indicate some of the inputs which affect the production cost of broiler meat in some EU countries, Brazil and USA compared to Serbia. Data refer to 2008, although differences between years have been moderate for longer period (Van Horn, 2006; Milošević and Perić, 2008; Rodić et al. 2010). It is observed that cost of food in Serbia is significantly higher compared to surrounding countries, and especially compared to Brazil and USA, even though Serbia is significant producer of corn, sunflower and soybean which are main ingredients in production of mixtures used in production of broiler chickens. The other important item in the cost structure is cost of one day old chick which is by $50 \%$ higher than in most of observed countries. Reasons for this are in the lack of organization and poor utilization of genetic potential of parent hen flocks (Milošević and Perić, 2007; 2008).

Table 4. Production parameters - table eggs

\begin{tabular}{|l|c|c|c|c|c|c|c|c|}
\hline Parameters & NL & D & F & ES & PL & BR & SAD & SRB \\
\hline Cost of food (Euro/100 kg) & 20,2 & 20,2 & 19,5 & 21,7 & 20,7 & 17,5 & 15,4 & 23,6 \\
\hline Cost of 17week old hens (Euro) & 2,93 & 2,94 & 2,91 & 2,77 & 2,79 & 2,00 & 2,05 & 4,5 \\
\hline Price of eggs (Euro/kg) & 0,87 & 1,50 & 1,07 & 1,38 & 1,00 & 0,77 & 0,71 & 1,86 \\
\hline Period of exploitation (days) & 400 & 385 & 355 & 393 & 400 & 395 & 400 & 370 \\
\hline Eggs/layers (pieces) & 334 & 325 & 296 & 318 & 317 & 316 & 324 & 286 \\
\hline Egg mass (grams) & 62,4 & 62,0 & 63,3 & 63,4 & 63,0 & 62,0 & 61,3 & 62,6 \\
\hline Feed conversion & 2,04 & 2,13 & 2,11 & 2,15 & 2,14 & 2,15 & 2,09 & 2,34 \\
\hline Mortality of layer hens (\%) & 6,5 & 6,8 & 6,5 & 8,0 & 8,7 & 8,0 & 7,5 & 9,9 \\
\hline
\end{tabular}

Source: SGJ (2010); Faostat (FAO.org); Van Horne (2008). 
Table 4 gives the comparative review of major production parameters in production of table eggs in 2008. The situation is repeated. In Serbia, price is increasing every year and it is significantly higher compared to other countries presented in this review. Kilogram of eggs in Serbia, according to data of FAOSTAT (2008) was 1,86 Euros and it is 1,4 times higher compared to USA. It is observed that almost all inputs are significantly more expensive than in other countries. In Serbia, price of hen at the age of 17 weeks is 4,5 Euros, and in Brazil only 2 Euros. In Germany, where already in significant percentage enriched cage system is used in housing of layer hens, price of eggs is lower than in Serbia.

In order to have insight into reasons for such high production price of table eggs, in Table 5 the review of the efficiency of utilization of heavy and light hybrid parent flocks is presented. The facts indicate that not only the objective circumstances influence the increase of production cost of poultry meat and eggs, but also subjective ones. Production potential of the flock is used below $2 / 3$ of its capacity which considerably increases the price of one day old chicks. This situation is not sudden, but rather has been present in Serbian poultry production for long period (Perić et al. 2002; Milošević and Perić, 2008). Data shows that per housed hen of broiler parents only 108 hatching eggs are produced, of 170 eggs which are foreseen according to the production technology, and also 85,9 one day old chicks produced which is only 59,3\%. Losses occur often in flocks, and together with low production of eggs, consumption/use of food per hatching egg is exceptionally high. Producers' excuse is the poor quality of parent flocks, old equipment, poor quality of food and lack of available medicines, but it is not always quite so. Many flocks are very good, but due to lack of cooperation between producers, unnecessarily large number of parent flocks is reared resulting in hyperproduction and inability to market broiler chickens and premature end of the production cycle of main flocks. Data show that flocks are being culled from the production cycle already at the age of 50 weeks. Data in Table 5 refer to parent flocks in Vojvodina for 2009.

Table 5. Use of production potential of broiler and parent light hybrids on farms

\begin{tabular}{|l|c|c|c|c|c|c|}
\hline \multirow{2}{*}{ Parameters } & \multicolumn{3}{|c|}{ Broiler parents } & \multicolumn{3}{c|}{ Light hybrid parents } \\
\cline { 2 - 7 } & $\begin{array}{c}\text { Techn. } \\
\text { norm }\end{array}$ & $\begin{array}{c}\text { Realized } \\
\text { product. }\end{array}$ & Index & $\begin{array}{c}\text { Techn. } \\
\text { norm }\end{array}$ & $\begin{array}{c}\text { Realized } \\
\text { product. }\end{array}$ & Index \\
\hline Duration of prod., weeks & 42 & 27,6 & 65,7 & 52 & 37 & 71,5 \\
\hline Hen losses, \% & 8 & 15,1 & 188 & 7 & 11,1 & 158 \\
\hline Cock losses, \% & 8 & 20,2 & 252 & 8 & 14,7 & 184 \\
\hline Eggs per housed hen, pieces & 180 & 124 & 68,9 & 264 & 178,3 & 67,5 \\
\hline Hatching eggs, pieces & 170 & 108 & 63,5 & 256 & 161,3 & 63,0 \\
\hline Use of food per egg, ${ }^{2}$ g & 270 & 318 & 117,8 & 184 & 237 & 129 \\
\hline Chicks/housed hen & 145 & 85,9 & 59,3 & $100^{*}$ & $67,8^{*}$ & 67,8 \\
\hline
\end{tabular}

*Female chickens/housed hen 
Use of parent of light line hybrids hasn't improved over the years (Peric et al. 2002; Milošević and Perić, 2008). Flocks remain in production for very short time, with high mortality rate, high use of food per produced egg and low percentage of produced commercial female chickens. So, it is not surprising that one 17 week old hen in production of table eggs is sold for 4,5 Euros, instead of much lower price which could be achieved with better management.

\section{Prospect of development of poultry production in Republic of Serbia}

Contrary to the gloomy picture of the situation in Serbian poultry production in previous years, today it shows visible signs of recovery and on many farms good results are achieved, but in general it is still an inefficient production with lot of problems. Many business operators in this branch still operate within semi-intensive, inefficient production system. In the previous period, several programs have been developed to improve this branch of economy, which have been partially implemented. Almost each of the programs anticipated annual growth of production of 2 to $3 \%$ in order to be able to realize the goal - annual production of 115000 tons of poultry meat $(15,7 \mathrm{~kg} / \mathrm{per}$ capita) and 180 billion table eggs (245 eggs/per capita) in Serbia by 2015. These expectations however are unrealistic, but this goal could be achieved by 2020. In order for this plan to be realized, considering present circumstances and development trends in Republic of Serbia, the following measures divided into several groups need to be implemented:

- Program of measures for revitalization of poultry production through engagement of existing capacities on big farms and family farms of medium capacity

- Reconstruction of existing farms and building of new ones where modern, high quality and functional equipment will be provided

- Provision of live material of high genetic value by import of line hybrids of guaranteed production qualities

- Provision of high quality animal food for all poultry species and categories

- Provision of good quality vaccines and medicines used in poultry protection and prevention

- Solving of problems of rational use of poultry slaughterhouses and processing capacities for poultry meat, eggs and poultry meat and egg products

- Expansion of capacities in all production segments according to current standards, primarily in EU

- Activities focused on finding new markets for poultry production 
- Planned harmonization between producers aimed at defining the needs in regard to import of needed number of main poultry flocks in order to avoid shortages and hyper production in production of hatching eggs and one day old chicks

- Introduction of new production programs from alternative poultry housing systems oriented towards export to EU countries

- Support of the government through various forms of credits and incentives.

Possibilities for development of poultry breeding in Republic of Serbia exist and maximum efforts should be made to move this production towards full upwards line of development. Prospect of poultry production is in further intensifying and more efficient utilization of production potentials, introduction of modern technologies with maximal mechanisation and automatisation of the production processes. In our production conditions, in future period, efforts should not be directed towards increase of number of hens, rather towards increase of number of other poultry species, primarily turkeys, geese and ducks. Also, efforts should be directed towards introduction of new high yielding and productive hybrids resulting in production of more meat and eggs of better quality, as well as new programs of alternative poultry rearing systems. In this way, this branch of livestock production will be of much greater use and benefit in future than it is today.

\section{Conclusion}

In general, poultry production of Republic of Serbia, since the disintegration of SFRY, showed continuous growth in absolute number of poultry, but also in productivity. In Republic of Serbia, in the late 80 -ties, $13 \mathrm{~kg}$ of poultry meat and 230 eggs was produced per capita, and in the mid 90-ties it dropped to very low level of only $6 \mathrm{~kg}$ of meat and 109 eggs per capita. There were several reasons for this drastic drop, military actions in the surrounding countries, introduction of economic sanctions, long transition processes and general decrease of the standard of living of population, but also many subjective deficiencies. Recovery of Serbian poultry production starts in 2000, but it is very slow mainly due to general economic situation in Serbia. It is anticipated that poultry production will reach full expansion before 2020, when it will be full capable to compete with leading EU countries, since there are natural resources for this, provided that until that time all transition processes have ended, that the credit rating of the country is stronger and certain organizational problems are solved, primarily forming of associations based on interest of all stakeholders in the chain of production of poultry meat and eggs.

\section{Acknowledgment}

Research was part of the project TR 31033 financed by the Ministry of Education and Science, Republic of Serbia. 


\title{
Stanje, kapaciteti i perspektiva razvoja živinarstva u Srbiji
}

\author{
N. Milošević, Z. Pavlovski, L. Perić
}

\section{Rezime}

U radu je ukratko prezentovan pregled stanja, kapaciteti i perspektiva živinarske proizvodnje u R. Srbiji. Konstatovano je da je proizvodnja u živinarstvu od 1990.-2000. godine uglavnom bila u stagnaciji. Od maksimalne proizvodnje mesa od $13,2 \mathrm{~kg} /$ stanovniku u 1988. godini pala je na ispod $6 \mathrm{~kg} \mathrm{u} \mathrm{1994.} \mathrm{godini} \mathrm{i} \mathrm{proizvodnja}$ jaja sa 230 komada/stanovniku u 1989. godini smanjila se na 109 jaja u 1995. Navedeno je da su razlozi lošeg stanja, uvođenje ekonomskih sankcija, tranzicioni procesi i pad životnog standarda stanovništva. Početak oporavka živinarske proizvodnje počinje nakon 2000. godine, kada su se donekle prilike u R. Srbiji promenile: izvršena je vlasnička transformacija preduzeća, ukinute su sankcije i počeo je priliv stranih kredita u našu zemlju. Oporavak ide vrlo sporo i predviđanja su da će se ova grana stočarstva u potpunosti revitalizovati do 2020. godine kada će biti dovoljno efikasna da proizvodima konkuriše razvijenim zemljama EU. Očekivanja su realna pod uslovom da se savladaju objektivne i subjektivne teškoće jer postoje prirodni resursi da se živinarstvo uspešno razvija i da obezbeđuje dovoljno proizvoda za domaće stanovništvo ali za izvoz posebno proizvoda iz alternativnih sistema proizvodnje.

\section{References}

BUGARIN M. (2010): Proizvodnja mesa i mleka. Privredna komora R. Srbije. http://pks.rs/PrivredauSrbiji/Poljoprivred/

ECONOMY/Poslovne vest/Privreda Srbije - statistika za jun 2010. godine. http://www.economy.rs

FAO, FAOSTAT, http://faostat.fao.org

LUKIĆ M., PAVLOVSKI Z., ŠKRBIĆ Z., MILOŠEVIĆ N., PERIĆ L. (2008):

The effect of housing system and hybrid type of layer hens on egg quality, 1st Mediterranean Summit of WPSA, Thessaloniki, Greece: University studio press, 710, 642-646.

MIHAILOVIĆ B., SUBIĆ J., SIMONOVIĆ Z. (2009): Strategy elements of export improvement in agro-economy of Serbia. Proceedings of the 9th International Conference "Investments and Economic Recovery", Bucharest.

MILOŠEVIĆ N., PERIĆ L., STRUGAR V., PAVLOVSKI Z. (2005): Rearing of fattening chickens on free range and extensively in chicken coop. Biotechnology in Animal Husbandry, 21, 5-6, 217-221. 
MILOŠEVIĆ N., PERIĆ L. (2007): Korišćenje proizvodnih potencijala živine u Vojvodini. Simpozijum "Veterinsrska medicina, stočarstvo i ekonomika u proizvodnji zdravstveno bezbedne hrane, Herceg Novi, Poljoprivredni fakultet, Novi Sad, 24.-30. jun, 2007. godine. Zbornik kratkih sadržaja, 138-139.

MILOŠEVIĆ N., PERIĆ L. (2008): Genetic potentials of poultry and their utilisation. Živinarstvo 1-2, 3-8.

MILOŠEVIĆ N., PERIĆ L. (2011): Tehnologija živinarske proizvodnje. Univerzitet u Novom Sadu, Poljoprivredni fakultet, Novi Sad.

MILOŠEVIĆ N., PERIĆ L., STRUGAR V. (2006): Sistemi proizvodnje živinskog mesa u skladu sa zahtevima tržišta. Savremena poljoprivreda, 55, 1-2, 206-211.

MUNĆAN P., ŠEVARLIĆ M., VASILJEVIĆ Z., ZARIĆ V. (2007): Situation and perspective for the meat sector in Serbia. Report of the FP6 project No 513705: Agro economic policy analysis of the new member states, the candidate countries and the countries of the Western Balkan. http://europartnersearch.net

PAVLOVSKI Z., ŠKRBIĆ Z., LUKIĆ M., KRNJAJA V., BIJELIĆ Z., TRENKOVSKI S. (2010): Tehnologija proizvodnje jaja sa slobodnog ispusta posebnog i garantovanog kvaliteta. Biotechnology in Animal Husbandry, 26, 41-55.

PERIĆ L., BOŽIĆ A., MILOŠEVIĆ N., SUPIĆ B. (2003): Raising chickens on a free range system. 1. Production parameters and healt status. Cresterea Animalelor in perspectiva integrarii Europene, Timisoara: Lucrari Stiintifice, Facultatea de Zootehnie si biotehnologii, vol. XXXVI, maj, 2003, 230-234.

PERIĆ L., MILOŠEVIĆ N., STRUGAR V. (2002): Production potentials stock of fowl in Vojvodina. Proceedings of 6th International Symposium Interdisciplinary Regional Research Hungary, Romania and Serbia and Montenegro, Novi Sad, Faculty of Agriculture, Novi Sad, 337-339.

PERIĆ L., MILOŠEVIĆ N., TOLIMIR N. (2008): Uticaj načina držanja i tipa hibrida na dobobit kokoši nosilja. Savremena poljoprivreda, 57, 1-2, 188-193.

PERIĆ L., TOLIMIR N., MILOŠEVIĆ N., STRUGAR V. (2002): Korišćenje proizvodnog potencijala roditeljskih jata živine u Srbiji u 2001. godini, Savremena poljoprivreda, 51, 3-4, 215-219.

RODIĆ V., PERIĆ L., ĐUKIĆ STOJČIĆ, M., MILOŠEVIĆ N. (2008): Uticaj načina držanja na osnovne ekonomske parametre proizvodnje konzumnih jaja, Biotechnology in animal husbandry, 24, 5-6, 237-243.

RODIĆ V., PERIĆ L., PAVLOVSKI Z., MILOŠEVIĆ N. (2010): Improving the poultry sector in Serbia: major economic constraints and opportunities. World's Poultry Science Journal, 66, 241-250.

STATISTIČKI GODIŠNJAK SRBIJE (2009): Savezni Zavod za Statistiku, Beograd

SUPIĆ B., MILOŠEVIĆ N., I ČOBIĆ T. (2000): Živinarstvo. Univerzitet u Novom Sadu, Poljoprivredni fakultet, Novi Sad. 
ŠKRBIĆ Z., PAVLOVSKI Z., LUKIĆ M., TOMAŠEVIĆ D. (2010): Tehnologija proizvodnje pilećeg mesa u sistemu gajenja sa ispustom. Biotechnology in Animal Husbandry, 26, 67-81.

VAN HORNE P.L.M. (2006): Broiler meat production costs differ per country. World Poultry, 22, 11, 17-18.

VAN HORNE P.L.M. (2007): Impact of EU and national legislation on production cost for broiler meat and eggs. Proceedings of the 16th European Symposium on Poultry Nutrition, Strasbourg, 423-427.

VAN HORNE P.L.M. (2008): Production cost broilers 2007 word $\backslash$ basicdata2007world.doc, LEI wageningen: peter.vanhorne@wur.nl

VAN HORNE P.L.M. (2008): Production costs comparison for layer in 2007. word \basicdata 2007-world.doc, LEI wageningen: peter.vanhorne@wur.nl

Received 30 June 2011; accepted for publication 15 August 2011 